Endocrinol. Japon. 1973, 20 (1), $77 \sim 80$

\title{
NOTE
}

\section{Improvement by Exogenous Cyclic AMP of Hereditary Vasopressin-Resistant Diuresis in Mice with Normal Adenyl Cyclase System of the Kidney Cells}

\author{
Motoyasu OHSAWA*, Narimichi KIMURA and Hiroyoshi ENDO** \\ Department of Physiological Chemistry, Faculty of Pharmaceutical Sciences, \\ University of Tokyo, Tokyo
}

\begin{abstract}
Synopsis
In an attempt to analyze the pathogenesis of hereditary vasopressin-resistant diabetes insipidus (DI) in mice associated with oligosyndactily (Os), possible participation of adenyl cyclase of the kidney cells in the mechanism of diuresis was examined.

In DI Os/ + mice with severe diuresis intraperitoneal injection of adenosine 3',5'-monophosphate (cyclic AMP) but not exogenous vasopressin delayed the onset of diuretic response to water load, while the reverse was true in DI $+1+$ mice with mild diuresis. Urinary osmolarity, moreover, was increased by cyclic AMP but not by vasopressin in Os $/+$ mice, whereas the reverse was the case with $+/+$ sibs. Although lack or defect of vasopressin-sensitive adenyl cyclase of the kidney cells might be assumed in the severely diuretic mice, both the basal and vasopressin-activated adenyl cyclase activities in vitro were similar between Os/ + and $+/+$ animals. The defect of vasopressin-sensitive adenyl cyclase in the kidney thus does not seem to be responsible for the hereditary nephrogenic diuresis of mice.
\end{abstract}

Falcorner et al. (1964) reported on hereditary diabetes insipidus (DI) in mice with the DI gene(s) linked together with a dominant gene responsible for oligosyndactily (Os). The severe nephrogenic diabetes insipidus in DI Os/ + mice was found to be resistant to exogenous vasopressin (Naik and Valtin, 1969; Stewart and Stewart, 1969) despite high vasopressor and oxytocic activities in the pituitaries (Naik and Kobayashi, 1971). The lack of responsiveness of the kidney to vasopressin thus appears to represent the main metabolic disorder in the mice.

In the present study, the effect of exogenous

Received for publication December 7, 1972.

* Present address: Department of Occupational Diseases, National Institute of Industrial Health, Kizuki-Sumiyoshi, Kawasaki.

** Reprint requests should be addressed to Dr. Hiroyoshi Endo, Department of Physiological Chemistry, Faculty of Pharmaceutical Sciences, University of Tokyo, Tokyo 113. adenosine $\quad 3^{\prime}, 5^{\prime}$-monophosphate (cyclic AMP), a messenger of vasopressin action according to Orloff and Handler (1967), on the syndrome of diabetes insipidus was therefore tested, along with the measurement of changes of cyclic AMP-synthesizing activity of the kidney cells in response to vasopressin in vitro.

\section{Materials and Methods}

Following two types of DI mice were used: a) DI $+1+$ mice having the DI gene(s) alone, with mild urinary concentrating defects, b) DI Os/ + mice having both DI gene(s) and Os gene, with severe diabetes insipidus. These mice were kindly supplied from breeding stocks by Dr. H. Kobayashi. All the tests in this work were carried out on 12- and 18week-old female mice.

Lysine-vasopressin was purchased from Sigma Chemical Co. (St. Louis, U.S.A.); cyclic AMP was kindly provided by Kyowa Hakko Indust. Co., Ltd. (Tokyo, Japan). 
Measurement of diuretic response to water load

Eighteen-week-old DI mice (4 animals for Os/ + and $+/+$ groups respectively) were placed each in an individual metabolic cage and loaded intraperitoneally with $1 \mathrm{ml}$ of $0.2 \% \mathrm{NaCl}$ solution per $10 \mathrm{~g}$ body weight as described by Silvette (1940). The urine was collected in small graduated cylinders to measure the volume every $15 \mathrm{~min}$ after the water load except for the first $15 \mathrm{~min}$. In each animal, the first experiment for cyclic AMP (50 $\mu \mathrm{g}$ per $\mathrm{g}$ body weight) was performed $24 \mathrm{hr}$ after the above control measurement and the second experiment for vasopressin (1 $\mathrm{mU}$ per $\mathrm{g}$ body weight) was carried out $48 \mathrm{hr}$ after the first experiment. The test materials dissolved in the saline were intraperitoneally injected. Time length of the "diuretic lag", which was defined as the projection of the steep part of the curve of cumulative excretion back onto the time axis (Stewart, 1968), indicates the anti-diuretic activity of the test substance. In addition, the osmotic pressure of 120-min urine samples pooled from four mice of each group was measured with the Fiske Osmometer (Fiske Associates, Inc., Bethel, Conn., U.S.A.).

\section{Measurement of cyclic AMP-synthesizing activity of kidney cells}

Levels of newly synthesized cyclic AMP in the isolated kidney cells were measured by a recently developed radioassay method (Ohsawa and Endo, 1972).

The kidney cells of $10 \mathrm{DI} \mathrm{Os} /+$ and $6 \mathrm{DI}+/+$ mice at the age of 12 weeks were dispersed by diges. ing the minced tissue with collagenase and hy. aluronidase. After preincubation of the cells with adenine $-8-{ }^{14} \mathrm{C}$, fresh medium containing theophylline with or without vasopressin was added to the labelled cells suspended in modified Krebs-Ringer-bicarbonate buffer ( $\mathrm{pH}$ 7.4). After further incubation for $20 \mathrm{~min}$, carrier solution containing adenine, adenosine, ATP cyclic AMP and ${ }^{3} \mathrm{H}$-cyclic AMP was added to the samples. Cyclic AMP fraction was obtained by combining purification procedures, $\mathrm{BaSO}_{4}$ treatment and cellulose thin-layer chromatography. ${ }^{14} \mathrm{C}$ and ${ }^{3} \mathrm{H}$ radioactivities of the fraction were measured in toluene scintillator medium by a scintillation counter. The radioactivity of ${ }^{14} \mathrm{C}$-cyclic AMP corrected on the basis of the recovery of tritium counts of ${ }^{3} \mathrm{H}$-cyclic AMP indicated the cyclic AMP-synthesizing activity of the kidney cells.

\section{Results}

Exogenous vasopressin and cyclic AMP were at first examined for the effect on diuresis in DI Os $/+$ and $+1+$ mice. As shown in Figure 1, intraperitoneal injection of vasopres. sin in $0.2 \% \mathrm{NaCl}$ solution definitely increased the "diuretic lag" in $+1+$ mice, whereas the anti-diuretic hormone gave no effect in $\mathrm{Os} / \mathrm{t}$

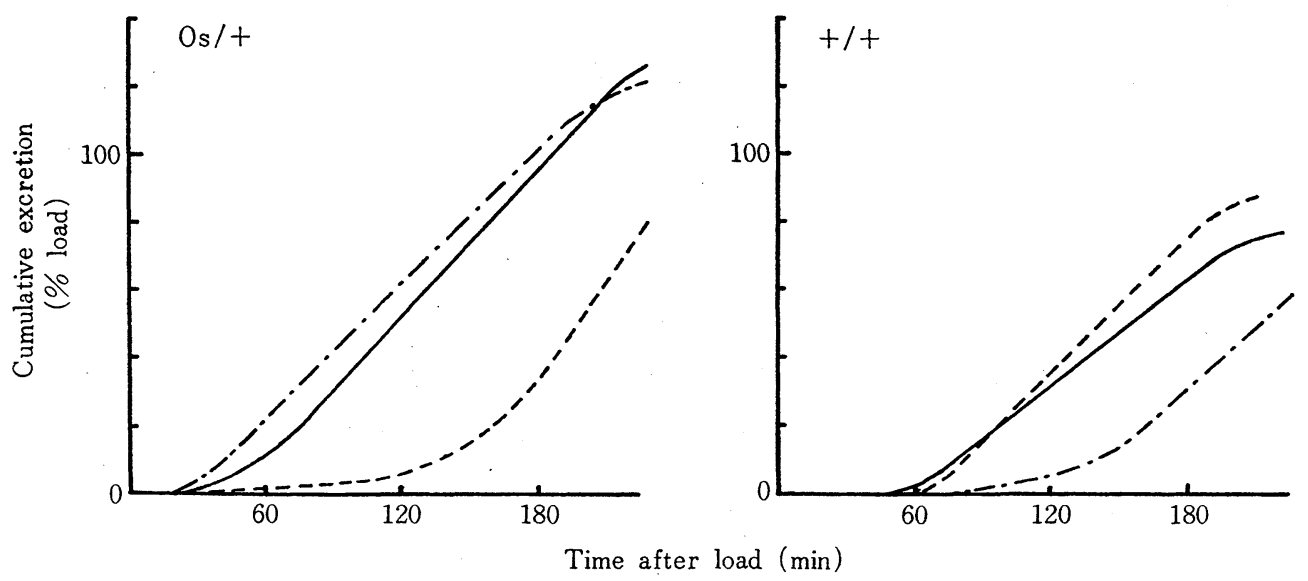

Fig. 1. Effect of exogenous vasopressin and cyclic AMP on diuretic responses to water load in DI Os $/+$ and $+1+$ mice. Each curve represents the arithmetic mean of individual curves of four mice.

- ; water-load alone $(0.2 \% \mathrm{NaCl} 1 \mathrm{ml} / 10 \mathrm{~g}$ body weight $)$.

----; water-load plus cyclic AMP (50 $\mu \mathrm{g} / \mathrm{g}$ body weight).

-.---; water-load plus vasopressin $(1 \mathrm{mU} / \mathrm{g}$ body weight $)$. 
sibs. On the contrary, cyclic AMP increased the diuretic lag in Os $/+$ mice but not in $+1+$ siblings.

The osmolarity of pooled urine samples was then determined. It is clear from Figure 2 that exogenous vasopressin increased urine osmolarity by 3.1 times in $+!+$ mice but not at all in Os/ + sibs, while cyclic AMP increased it by 1.6 times in $\mathrm{Os} /+$ mice but not in $+1+$ siblings.

These results might indicate a possible

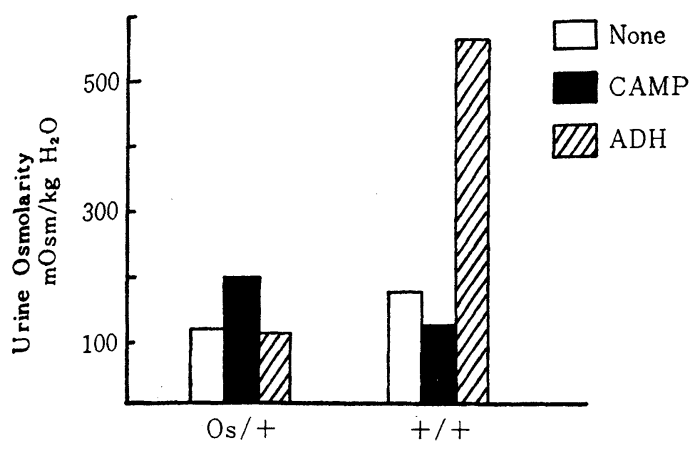

Fig. 2. Effect of exogenous vasopressin and cyclic AMP on urine osmolarity. Each column shows osmolarity of the urine collected over a $120 \mathrm{~min}$ period after beginning of the measurement of diuretic response. Each value represents the mean of pooled urine samples from four mice. None; water-load alone, cAMP; cyclic AMP treated ( $50 \mu \mathrm{g} / \mathrm{g}$ body weight), ADH; vasopressin treated ( $1 \mathrm{mU} / \mathrm{g}$ body weight).

Table 1. ${ }^{14} \mathrm{C}$-cyclic AMP level and its change by vasopressin in the isolated kidney cells of DI Os $/+$ and $+1+$ mice

\begin{tabular}{cccc}
\hline & & \multicolumn{1}{c}{$\begin{array}{c}{ }^{14} \mathrm{C} \text {-cyclic AMP } \\
\left(\mathrm{dpm} \times 10^{-4} / \mathrm{g} \text { cells }\right)\end{array}$} \\
\hline $\mathrm{Os} /+$ & Control & $14.47 \pm 1.18$ & \\
& & \\
& Treated & $16.52 \pm 1.24$ & $(116 \%)$ \\
& Control & $13.14 \pm 0.98$ & \\
& Treated & $15.57 \pm 1.20$ & $(120 \%)$ \\
\hline
\end{tabular}

For experimental conditions see Materials and Methods. Vasopressin $(2 \mathrm{mU} / \mathrm{ml})$ in the presence of $3 \mathrm{mM}$ theophylline was added to the kidney cell suspension. Results were given as mean \pm standard error $(n=4)$. Percentages were given for the treated to the control. impairment of vasopressin-sensitive cyclic AMP-forming system in the kidney of Os/t mice. As shown in Table 1, however, the dissociated kidney cells from $\mathrm{Os} /+$ and $+1+$ mice gave much the same level of basal activity of adenyl cyclase, and the enzyme in both preparations was stimulated by vasopressin to a similar extent, though not statistically significant but comparable to that in normal rat kidney cells (Ohsawa and Endo, 1972).

\section{Discussion}

In cases of pseudohypoparathyroidism Chase et al. (1969) suggested lack or defective form of parathyroid hormone-sensitive adenyl cyclase in bone and kidney. The explanation was based on the excretion of subnormal amount of cyclic AMP in the patients despite abnormally high concentration of parathyroid hormone in circulating blood as well as the failure of increase of the cyclic nucleotide excretion through exogenous parathyroid hormone, though some questions have recently been raised (Marcus et al., 1971; Bell et al., 1972).

It is to be noted that the hereditary nephrogenic diabetes insipidus of DI Os/ + mice reported by Falcorner et al. (1964) is similar in endocrine situation to the clinical pseudohypoparathyroidism. Namely, despite the high vasopressor activity in the pituitaries (Naik and Kobayashi, 1971), the mice with severe diuresis was completely lacking in the responsiveness to vasopressin (Naik and Valtin, 1969). In addition to the reconfirmation of the impaired response to anti-diuretic hormone, definite anti-diuretic effect of exogenous cyclic AMP was demonstrated in the present study (Fig. 1 and 2). In spite of these findings suggesting a possible impairment of vasopressin-sensitive adenyl cyclase in the kidney, however, a rather marked adenyl cyclase activity with possible vasopressin-sensitivity were demonstrated in the dissociated kidney cells of the mice (Table 
1). As to the basal activity, whether or not the level represents the normal basal activity remains yet unsettled principally because of the lack for data of normal mice. As to the vasopressin-responsiveness, on the other hand, the stimulation was not statistically significant in the presenst experiment. This is probably due to the cell preparation as a mixture of all kinds of renal cells containing a large amount of cortical cells lacking the response of adenyl cyclase to the anti-diuretic hormone (Marumo and Edelman, 1971; Beck et al., 1971). However, in view of the the fact that the basal enzyme activity and its hormone sensitivity in the mice were fully comparable to those of the kidney cell preparation similarly prepared from normal rats (Ohsawa and Endo, 1972), the lack or defective form of vasopressin-sensitive adenyl cyclase in the kidney does not appear to be responsible for the development of diabetes insipidus in $\mathrm{Os} /+$ mice.

For a satisfactory explanation of these findings, the following possibilities remain to be considered. (1) Abnormally high leak of cyclic AMP out of the kidney cells of Os/+ mice; Urakabe et al. (1970) pointed out the importance of leakage of cyclic AMP from the cells as one of the factors affecting intracellular cyclic AMP concentration. (2) Abnormal high concentration of a factor or factors inhibiting the vasopressin action through interaction with the vasopressin receptor site of the cells without affecting the action of cyclic AMP, like prostaglandin $\mathrm{E}_{1}$ (Marumo and Edelman, 1971; Beck et al., 1971) and catecholamines (Beck et al., 1972), in the interstitial space near the renal epithelial cells of Os/+ mice. (3) Increased systemic activity of inactivating vasopressin in Os/ + mice; vasopressin has been known to be inactivated in the kidney and liver (Birnie, 1953; Zaidi, $1955)$ and accelerated inactivation of vasopres- sin was observed in patients with diabetes insipidus (Hankiss, 1958). Further works to explore these possibilities are under way.

\section{References}

Beck, N. P., T. Kaneko, U. Zor, J. B. Field and B. B. Davis (1971). J. Clin. Invest. 50, 2461.

Beck, N. P., S. W. Reed, H. V. Murdaugh and B. B. Davis (1972). Ibid. 51, 939.

Bell, N. H., S. Avery, T. Sinha, C. M. Clark, Jr., D. O. Allen and C. Johnston, Jr. (1972). Ibid. 51, 816.

Birnie, J. H. (1953). Endocrinology 52, 33.

Chase, L. R., G. L. Melson and G. D. Aurbach (1969). J. Clin. Invest. 48, 1832.

Falcorner, D. S., M. Latyszewski and J. H. Isaacson (1964). Genet. Res. 5, 473.

Hankiss, J. (1958). J. Clin. Endocr. 18, 543.

Marcus, R., J. F. Wilber and G. D. Aurbach (1971). Ibid. 33, 537.

Marumo, F. and I. S. Edelman (1971). J. Clin. Invest. 50, 1613.

Naik, D. V. and H. Valtin (1969). Am.J. Physiol. 217, 1183.

Naik, D. V. and H. Kobayashi (1971). Neuroendocrinology 7, 322.

Ohsawa, M. and H. Endo (1972). Endocrinol. Japon. 19, 251.

Orloff, J. and J. Handler (1967). Am. J. Med. 42, 757.

Silvette, H. (1940). Am. J. Physiol. 128, 747.

Stewart, J. (1968). J. Physiol. 198, 355.

Stewart, A. D. and J. Stewart (1969). Am. J. Physiol. 217, 1191.

Urakabe, S., D. Shirai, A. Ando, Y. Takemitsu, Y. Orita and H. Abe (1970). Jap. Circ. J. 34, 595.

Zaidi, Z. A. (1955). J. Endocrinol. 12, i. 